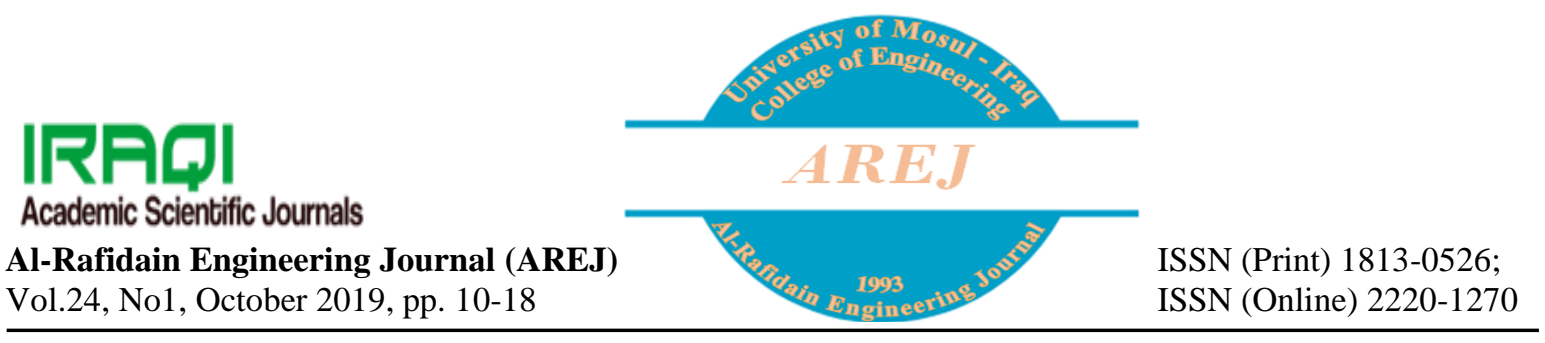

\title{
Theoretical Stress Analysis of Gas Turbine Blade Made From Different Alloys
}

\author{
*Suha Hashim Ahmed **Ghaidaa Ibrahim Husain ***Majeed Ali Abdulrazaq \\ Assistant Lecturer Assistant Lecturer Assistant Lecturer \\ Suhahasim98@gmail.com zahars2004@yahoo.com Majeed.abdulrazaq@uoz.edu.krd \\ *, ** Department of Mechanical Engineering, University of Mosul \\ *** Department of Mechanical Engineering, University of Zakhoo
}

Received: 19-11-2018

Accepted: 30-4-2019

\begin{abstract}
Blades may be considered to be the heart of turbine without blade there would be no power and the slightest fault in blade would mean a reduction in efficiency and costly repairs.

The centrifugal force is one of the problems faced by the designer of blades especially at the first stages. The designer aims at reducing the stresses with in the allowed limit.

The ANSYS 15 software was used as far as it is the most effective in analyzing the different numerous cases of stresses, the blades with limited root in all direction $(X, Y, Z)$ were taken into consideration. The centrifugal forces were applied on the rotor blades at running speed of 6000 r.p.m., The finite element models of the blade were constructed using D3-10noded Tetrahedron elements shape, SOLID 187, mesh of the entire blade 23406 Node,136575element. The average of normal stress, Von misses, Maximum principle stress, Minimum principle stress were calculated according to ANSYS 15 program, these stresses are as the result of the effect of centrifugal force for all planes along the blades and then values of stresses were compared to the curves for each alloy. The current research concluded that the Titanium alloy is the best alloy used in terms of reducing stresses due to centrifugal force, that is because density of Titanium alloy used is less than that of other used alloys, leading a reduction in centrifugal forcess that are directly proportional to mass.
\end{abstract}

\section{Keywords:}

Gas turbine blade; inconel 625, inconel 718 MarM-200; Titanium alloys; Centrifugal stress; ANSYS15; Stress analysis.

https://rengj.mosuljournals.com

Email: alrafidain_engjournal@umosul.edu.iq

\section{INTRODUCTION}

Shattering of turbine blades are one of the most critical troubles in power generating industry. Rotor blades are the very generally used machine parts used in high-technics applications and in general are used as a lot of arrangement mechanical element. These blades are subjected to different loads like centrifugal loading. Centrifugal forces is the main component participate in to the stress produced in the blades [1].

Centrifugal loads are formed by high rotational speeds at (6000 r.p.m).The formed Centrifugal force depend upon the size of the rotor and the rotational speed of the rotor. As it is well known, that the centrifugal force Fc can be defined as :

$\mathrm{Fc}=\mathrm{mrw}^{2}$, where, $(\mathrm{m})$ is the mass $(\mathrm{kg})$, (r) is the radius of rotation and $\mathrm{w}^{2}$ is the angular speed. Gas turbine blades alloys are designed mainly to protect the structural material against loads, corrosion, oxidation, erosion and high temperature environments.

The main reason of shut down in turbo machine is the shatter of rotor blade. The failure of the rotor blade may guide to serious consequences both physically and economically. Hence, the suitable design of the turbo machine blade plays a necessary role in the suitable functioning of the turbo machine [5]. 
In the current study, the first stage rotor blade of a two-stage gas turbine has been analyzed for structural static using ANSYS 15.0Software which is powerful Finite Element Software. In the process of getting mechanical stresses in the rotor blade has been evaluated using four different alloys; namely: Inconel 718, Inconel 625, MarM200,

Titanium alloys .And the dimensions of the blade for the current study shown in Table.1.The blade was cut into twenty one sections along the length of the Airfoil with ANSYS software as shown in Fig.1The finite element models of the blade were constructed using D3-10-noded Tetrahedron elements shape, SOLID 187, mesh of the entire blade 23406 Node, 136575 element as shown in Fig. 2. And all results take from the option of the average of stresses in ANSYS software as shown in Fig.3.

Table 1: Dimensions of the blade

\begin{tabular}{|c|c|c|c|}
\hline $\begin{array}{c}\text { Total length } \\
\text { of blade }\end{array}$ & $\begin{array}{c}\text { Length of } \\
\text { root }\end{array}$ & $\begin{array}{c}\text { Length of } \\
\text { Airfoil }\end{array}$ & $\begin{array}{c}\text { Length of } \\
\text { hollow }\end{array}$ \\
\hline $157 \mathrm{~mm}$ & $62 \mathrm{~mm}$ & $95 \mathrm{~mm}$ & $52.1 \mathrm{~mm}$ \\
\hline
\end{tabular}

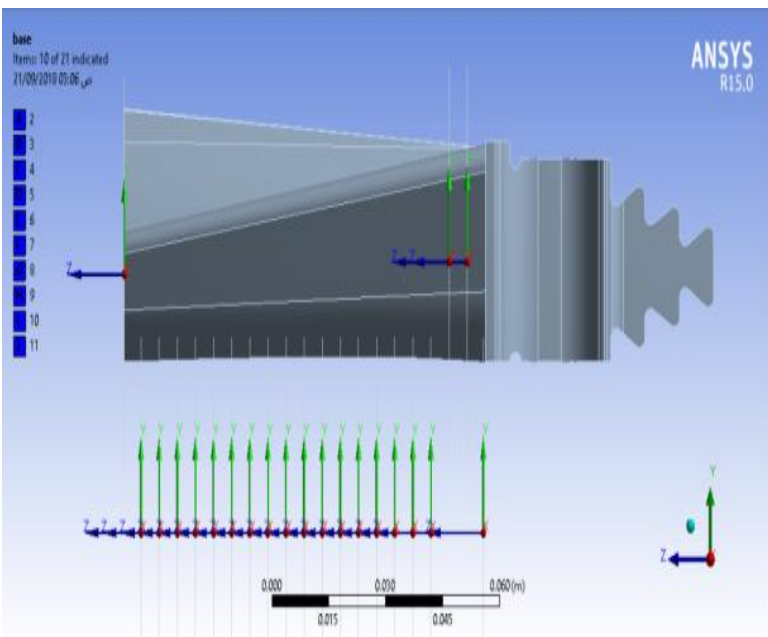

Fig. 1 Shown the sections along the length of blade used in the analysis

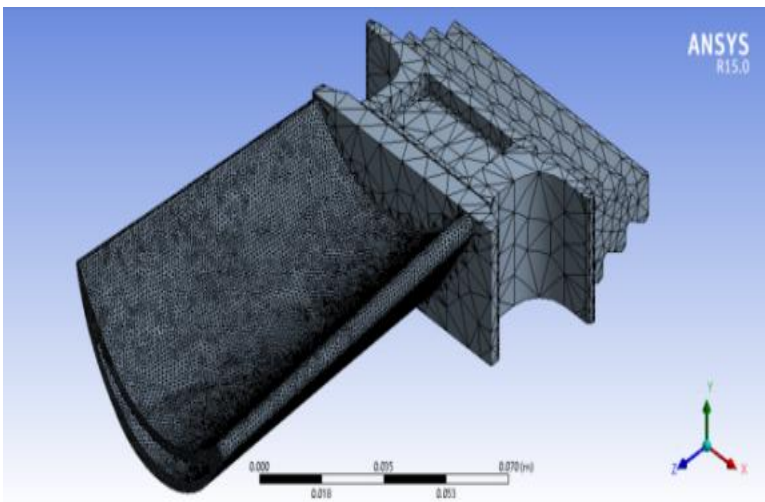

Fig. 2 Shows the generated finite element Mesh used in the current investigation

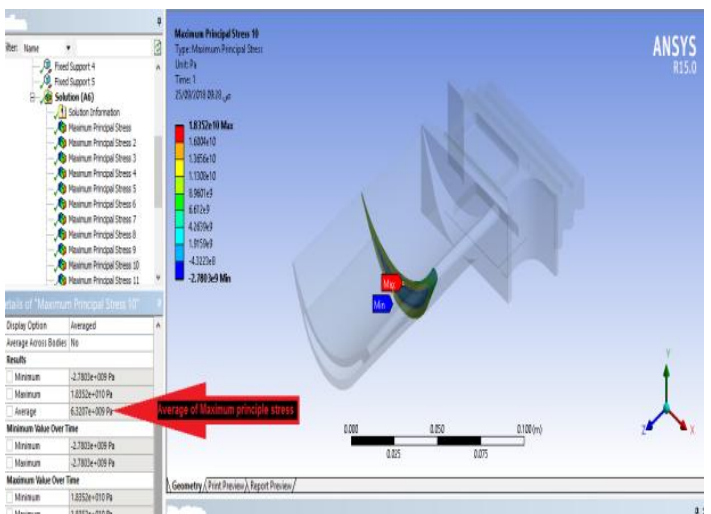

Fig. 3 Showsthe place of Max.principle stress in tenth section.

\section{LITERATURE RIVEW}

Theju et.al[8]had mainly done the research work on jet engines turbine blade; the study was done on two different materials Inconel718 and Titanium T-6 alloy to discuss the effect of temperature and induced stresses on turbine blade. The study complemented that the Titanium T-6 would have minimum value of deformation and lesser strength.

Naga Bhushana Rao et.al[9] had done research on turbine blade used in marine applications. The blade was observed for structural analysis at elevated temperatures and under the action of large centrifugal force, the material used was nickel based super alloy, it was investigated that high stresses and strains were observed near to the root of the turbine blade and upper surface along the blade root, maximum temperature is observed at the blade tip and minimum at the root of the blade.

\section{MATERIAL AND MATERIAL PROPERTIES}

Four alloys have been used in the current study:

\section{3-1- INCONEL 718\&INCONEL 625 alloys}

It is a high strength, heat resistant superalloy (HRSA) that is used extensively by the aerospace industry for the hot parts of gas turbine engines such as, turbine disks, blade .[2]

\section{3-2-Mar M-200 alloy}

The material of the blade is taken as MAR M-200 isconsider superNickel alloy. It is one of the proper material for blades of Gas turbineon account of its altitude yield strength, 
endurance limit and its ability to stop therising of temperatures [1].

\section{3-3-Titanium Alloy}

Accelerates formation of chromia at metal/oxide interface; decrease thermal expansion coefficient in $\mathrm{Ni}$ base alloys. These titanium alloys are foundamentlly used for represent materials for hard tissues.[3].

Table2: Mechanical properties of Inconel 625, MarM-200 \& Titanium alloy [6,4,1,3].

\begin{tabular}{|c|c|c|c|c|}
\hline Property & $\begin{array}{c}\text { Inconel6 } \\
25 \\
\text { alloy [6] }\end{array}$ & $\begin{array}{c}\text { Inconel7 } \\
18 \\
\text { alloy[4] }\end{array}$ & $\begin{array}{c}\text { MarM200 } \\
\text { alloy[1] }\end{array}$ & $\begin{array}{c}\text { Titanium } \\
\text { alloy[3] }\end{array}$ \\
\hline $\begin{array}{c}\text { Density } \\
\text { (kg / m }{ }^{3} \text { ) }\end{array}$ & 8400 & 8190 & 8526 & 4540 \\
\hline $\begin{array}{c}\text { Poisson's } \\
\text { ratio }\end{array}$ & 0.3 & 0.22 & 0.33 & 0.33 \\
\hline $\begin{array}{c}\text { Modulus } \\
\text { of } \\
\text { Elasticity } \\
\text { (Gpa) }\end{array}$ & 145 & 200 & 220 & 206.84 \\
\hline
\end{tabular}

\section{RESULTS AND DISCUSSIONS}

Following Fig.(4,to7) show the results of stress analysis in INCONEL625 alloy,we notice that the concentration of stresses rate is in the back of the base of the airfoil, which gradually decreases along the airfoil near the top of the blade, because the centirfugal force is higher at the base and lower at the top of the blade due to the decrease in the mass of blade whenever the direction from the base to the top of the blade and Table(3) show the average stresses on INCONEL625.

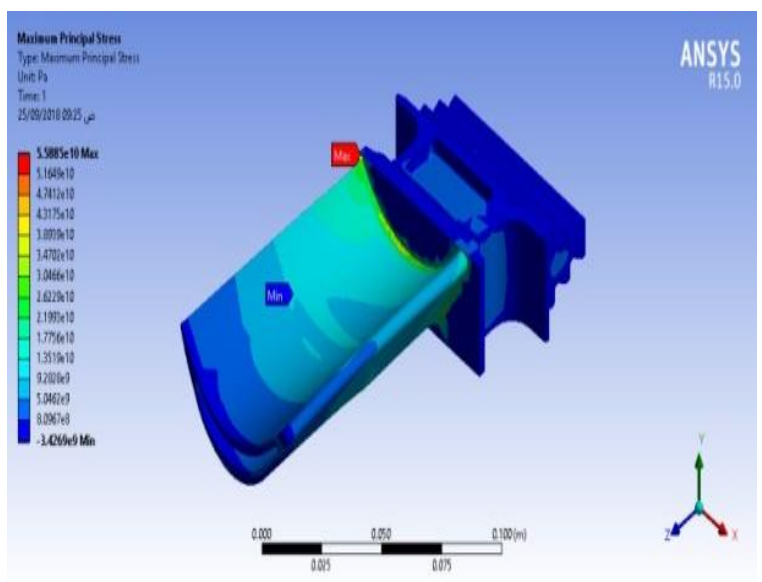

Fig. 4 Shows themaximum principle stress for INCONEL625 alloy.

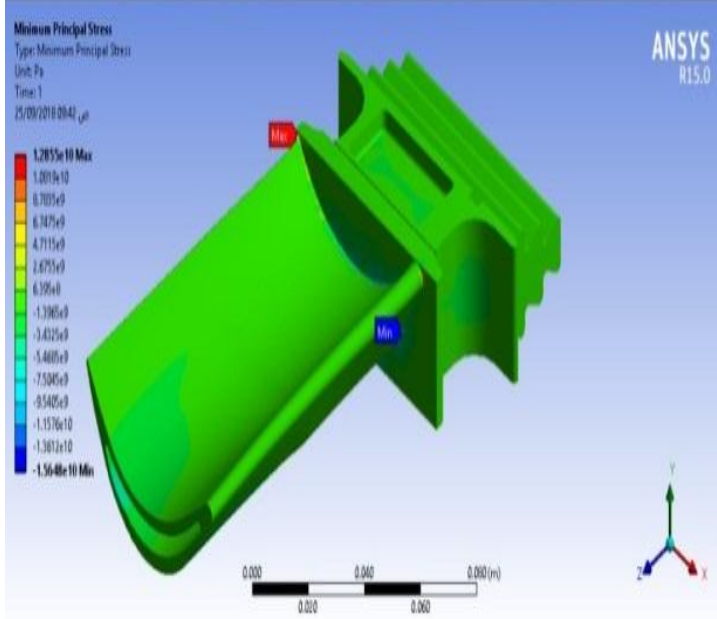

Fig. 5 Shows the minimum principle stress for the INCONEL625 alloy blade.

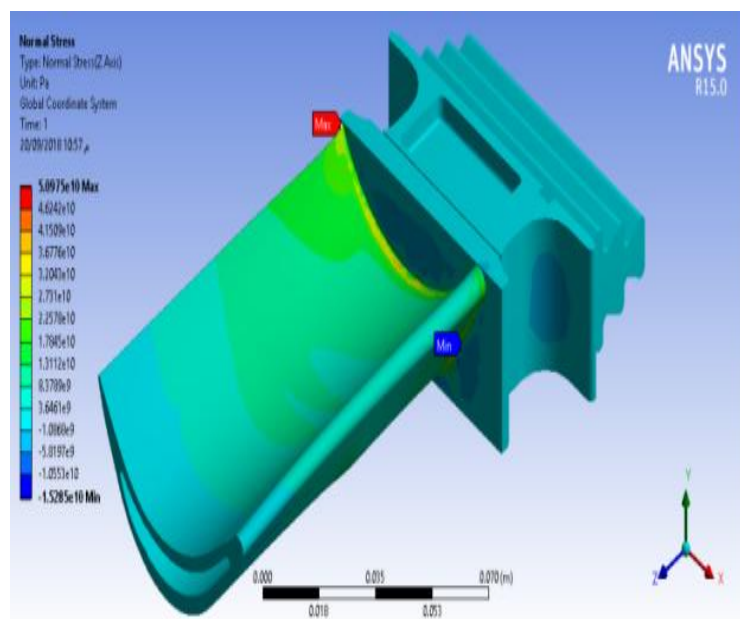

Fig. 6 Shows thenormal stress for the INCONEL625 alloy blade.

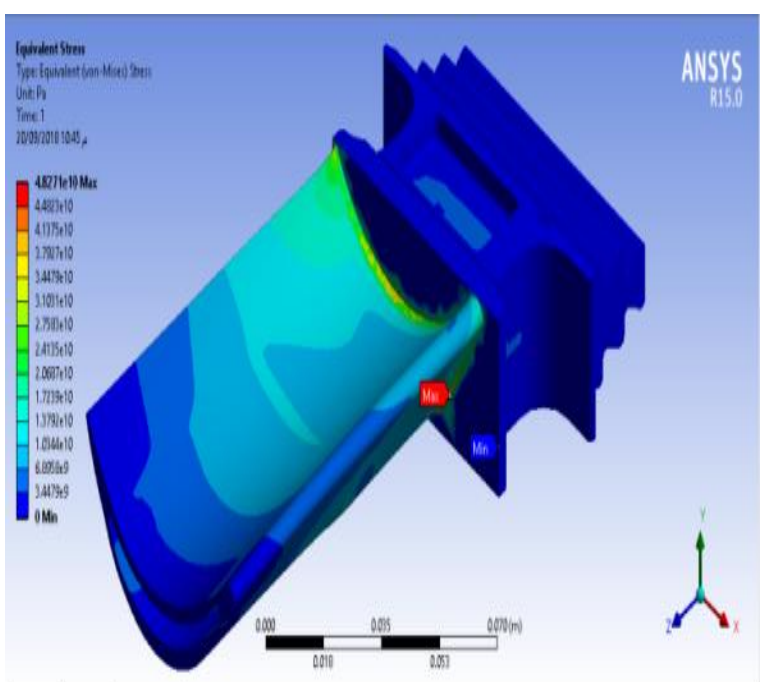

Fig. 7 Shows the Von misses stress for the INCONEL625 alloy blade. 
Table 3: Results of averge stress analysis of blade of gas turbine made from INCONEL625 alloy by ANSYS program at all sections along the blade.

\begin{tabular}{|c|c|c|c|c|}
\hline $\begin{array}{c}\text { Sectio } \\
\mathrm{n} \text { No. }\end{array}$ & $\begin{array}{c}\text { Normal } \\
\text { stress } \\
\text { (MPa) }\end{array}$ & $\begin{array}{c}\text { Von } \\
\text { misses } \\
\text { (MPa) }\end{array}$ & $\begin{array}{c}\text { Maximum } \\
\text { principle } \\
\text { stress } \\
\text { (MPa) }\end{array}$ & $\begin{array}{c}\text { Minimu } \\
\mathrm{m} \\
\text { principle } \\
\text { stress } \\
\text { (MPa) }\end{array}$ \\
\hline 1 & 11942 & 10300 & 12510 & 2520 \\
\hline 2 & 11700 & 10240 & 12030 & 1022 \\
\hline 3 & 11034 & 10250 & 11110 & 239 \\
\hline 4 & 10362 & 9950 & 10410 & 40 \\
\hline 5 & 9662 & 9454 & 9714 & 12 \\
\hline 6 & 8940 & 8865 & 9005 & 11 \\
\hline 7 & 8197 & 8201 & 8276 & -1 \\
\hline 8 & 7428 & 7452 & 7521 & -108 \\
\hline 9 & 6666 & 6939 & 6853 & -422 \\
\hline 10 & 6198 & 8243 & 6321 & -2367 \\
\hline 11 & 9423 & 9399 & 9480 & -124 \\
\hline 12 & 8517 & 8592 & 8579 & -148 \\
\hline 13 & 7602 & 7727 & 7666 & -121 \\
\hline 14 & 6678 & 6831 & 6744 & -296 \\
\hline 15 & 5748 & 5917 & 5811 & -349 \\
\hline 16 & 4800 & 4997 & 4866 & -395 \\
\hline 17 & 3846 & 4079 & 3914 & -439 \\
\hline 18 & 3000 & 3174 & 2954 & -488 \\
\hline 19 & 1908 & 2305 & 1999 & -541 \\
\hline 20 & 1300 & 1539 & 1115 & -600 \\
\hline 21 & 0.5 & 1302 & 100 & -788 \\
\hline
\end{tabular}

The following Fig. (8 to 11) show the stress analysis for INCONEL718 alloy,the result obtaained can be discussed as an ANSYS program where the value of the largest stress at the base of the airfoil and the lowest at the top of the blade is explained by the fact the high centrifugal force at the base of the airfoil and less as we movement to the top of the blade, and Table(4) show the average stresses on INCONEL 718.

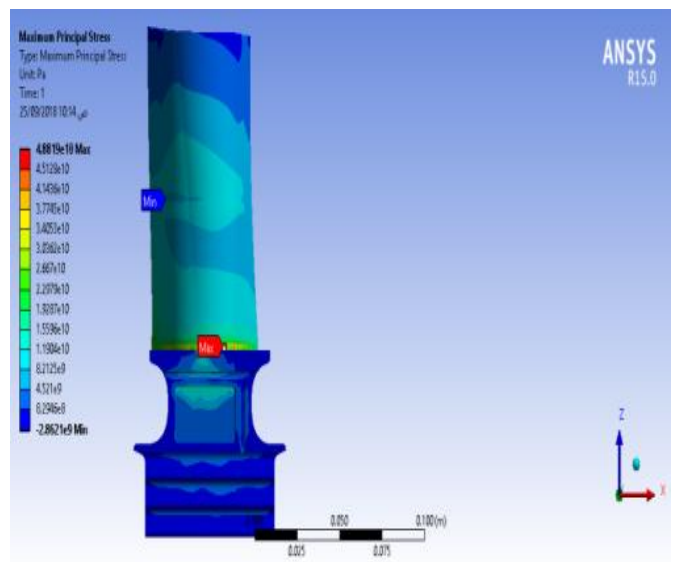

Fig. 8 Shows the maximum principle stress for the INCONEL718 alloy.

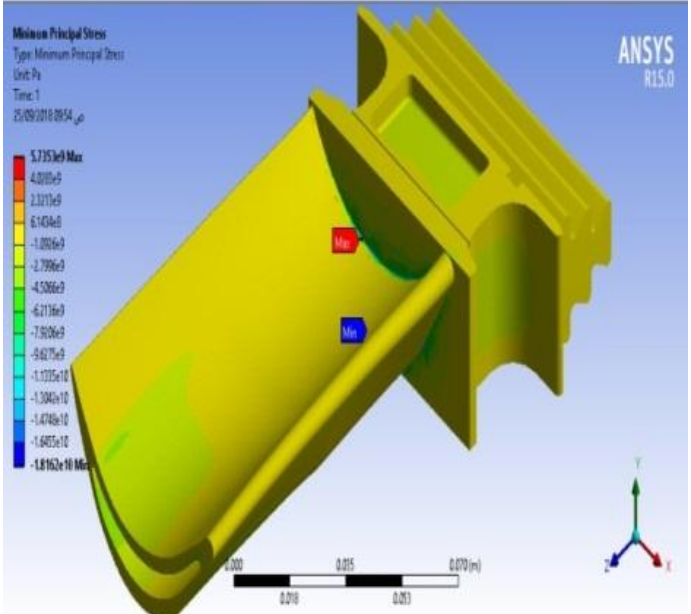

Fig. 9 Shows theminimum principle stress for INCONEL718 alloy.

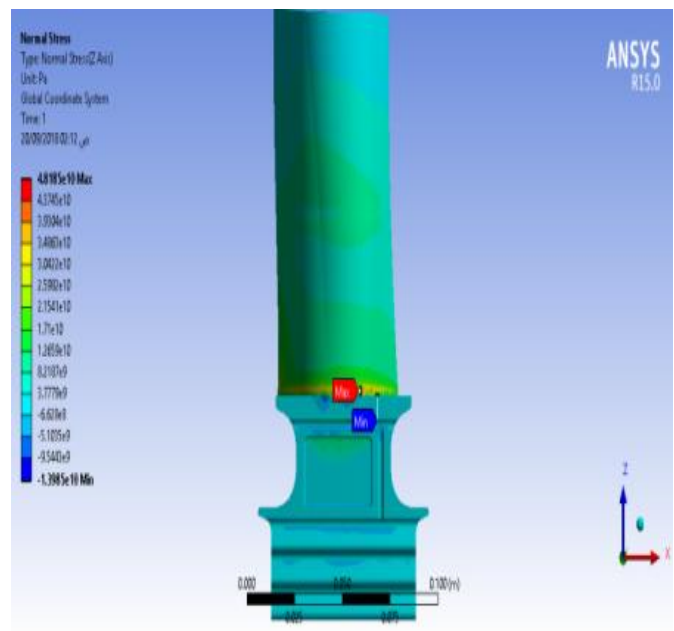

Fig. 10 Shows thenormal stress for INCONEL718 alloy.

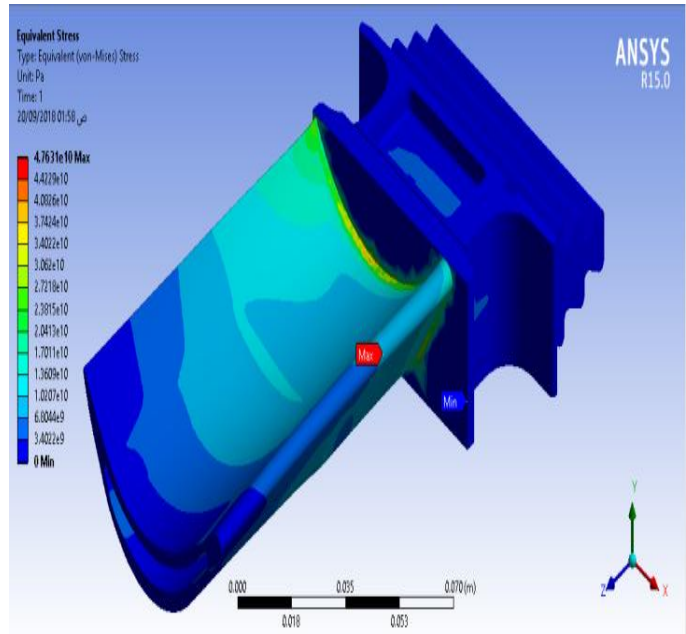

Fig. 11 Shows the Von misses stress for the INCONEL718 alloy. 
Table 4: Result of average stress analysis on blade of gas turbine made from INCONEL718 alloy by ANSYS programat all sections along the blade.

\begin{tabular}{|c|c|c|c|c|}
\hline $\begin{array}{c}\text { Section } \\
\text { No. }\end{array}$ & $\begin{array}{c}\text { Normal } \\
\text { stress } \\
\text { (MPa) }\end{array}$ & $\begin{array}{c}\text { Von } \\
\text { misses } \\
\text { (MPa) }\end{array}$ & $\begin{array}{c}\text { Maximum } \\
\text { principle } \\
\text { stress } \\
\text { (MPa) }\end{array}$ & $\begin{array}{c}\text { Minimum } \\
\text { principle } \\
\text { stress } \\
\text { (MPa) }\end{array}$ \\
\hline 1 & 12263 & 10278 & 11700 & 1664 \\
\hline 2 & 11423 & 10247 & 11680 & 896 \\
\hline 3 & 10750 & 10125 & 10820 & 234 \\
\hline 4 & 10103 & 9763 & 10150 & 38 \\
\hline 5 & 9421 & 9240 & 9474 & 7 \\
\hline 6 & 8716 & 8640 & 8782 & 5 \\
\hline 7 & 7993 & 7983 & 8071 & 4 \\
\hline 8 & 7241 & 7245 & 7335 & -70 \\
\hline 9 & 6498 & 6716 & 6680 & -331 \\
\hline 10 & 6060 & 8007 & 6192 & -2263 \\
\hline 11 & 9187 & 9238 & 7245 & -190 \\
\hline 12 & 8304 & 8400 & 4557 & -168 \\
\hline 13 & 7412 & 7535 & 4525 & -215 \\
\hline 14 & 6511 & 6655 & 4515 & -280 \\
\hline 15 & 5600 & 5765 & 3684 & -330 \\
\hline 16 & 4681 & 4868 & 2773 & -373 \\
\hline 17 & 3709 & 3970 & 1865 & -440 \\
\hline 18 & 2811 & 2799 & 1127 & -460 \\
\hline 19 & 1860 & 2237 & 1121 & -511 \\
\hline 20 & 899 & 1488 & 1090 & -572 \\
\hline 21 & 0.7 & 1234 & 559 & -748 \\
\hline & & & & \\
\hline
\end{tabular}

The following Fig. (12- to 15) show the resultof MarM-200 alloy blade,the highest value of the stresses is at the base of the airfoil,the reason is that the centrifugal force are high at the base of airfoil and decrease as we move up at the top of the blade this is due to the gradual reduction of the blade mass along the airfoil, and Table(5) show the average stresses on MarM-200.

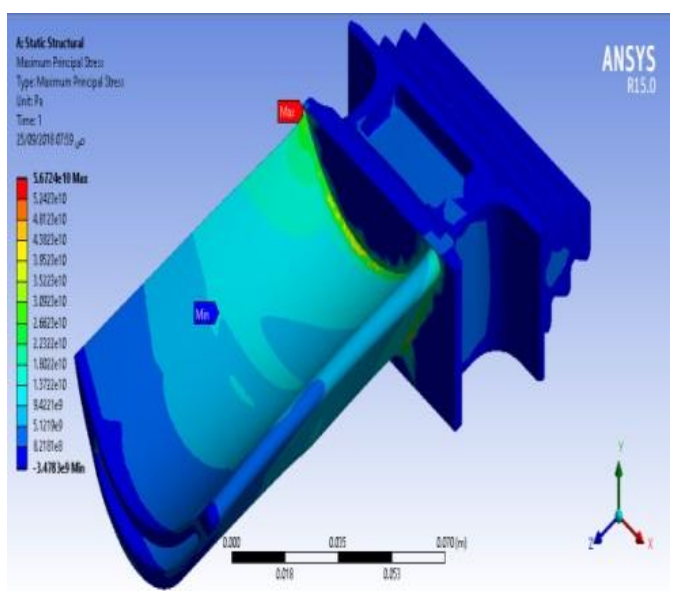

Fig. 12 Shows themaximum principle stress for Mar-M200 alloy.

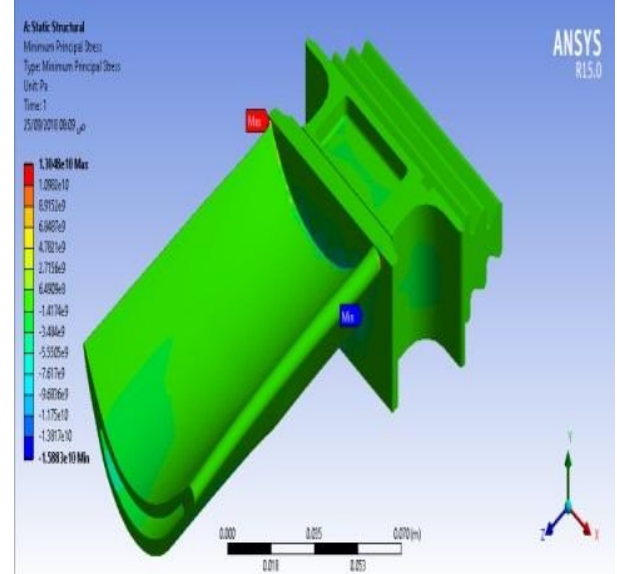

Fig. 13 Shows the minimum principle stress Mar M-200 alloy.

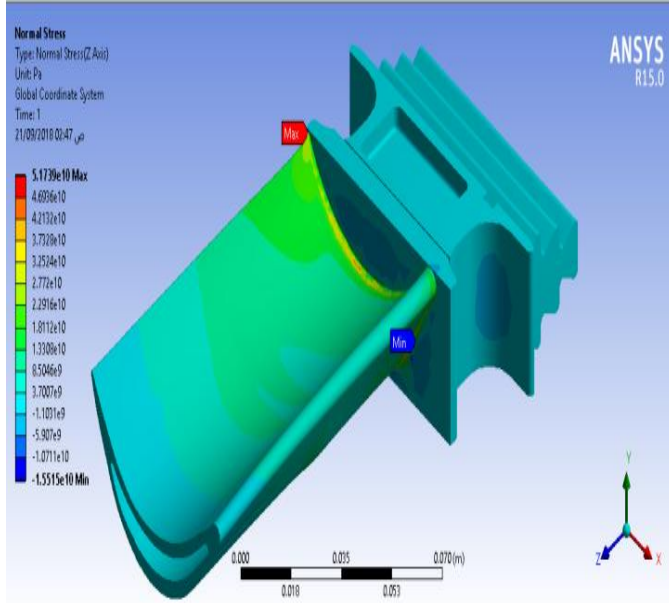

Fig. 14 Show the normal stress for Mar M-200 alloy.

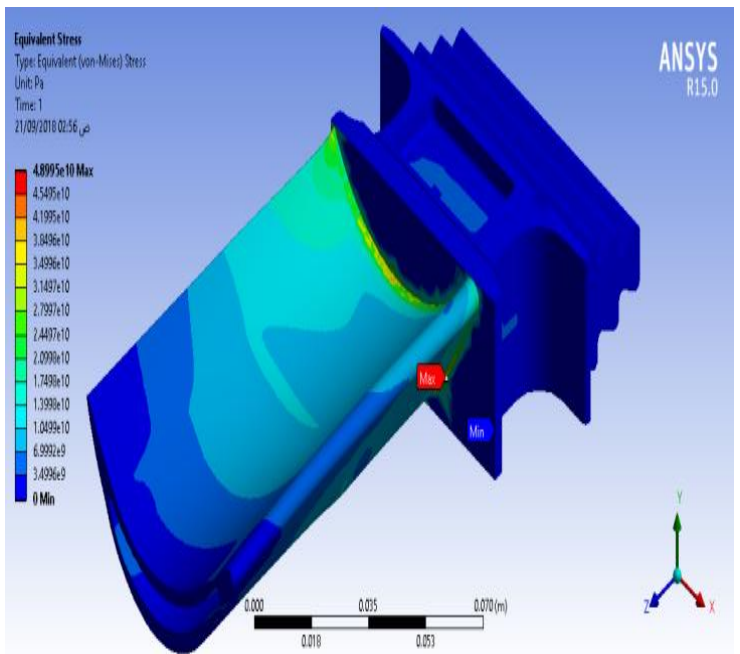

Fig. 15 Show theVon misses stress for Mar M200. 
Table 5: Result of average stress analysis on blade of gas turbine made from Mar M-200 alloy by ANSYS programat all sections along the blade.

\begin{tabular}{|c|c|c|c|c|}
\hline $\begin{array}{l}\text { Section } \\
\text { No. }\end{array}$ & $\begin{array}{l}\text { Normal } \\
\text { stress } \\
(\mathrm{MPa})\end{array}$ & $\begin{array}{c}\text { Von } \\
\text { misses } \\
(\mathrm{MPa})\end{array}$ & $\begin{array}{c}\text { Maximum } \\
\text { principle } \\
\text { stress } \\
\text { (MPa) }\end{array}$ & $\begin{array}{c}\text { Minimum } \\
\text { principle } \\
\text { stress } \\
\text { (MPa) }\end{array}$ \\
\hline 1 & 12100 & 10400 & 12690 & 2558 \\
\hline 2 & 11880 & 10390 & 12200 & 1037 \\
\hline 3 & 11199 & 10412 & 11280 & 243 \\
\hline 4 & 10518 & 10101 & 10560 & 41 \\
\hline 5 & 9808 & 9596 & 9859 & 12 \\
\hline 6 & 9074 & 8996 & 9140 & 11 \\
\hline 7 & 8320 & 8324 & 8400 & -2 \\
\hline 8 & 7539 & 7564 & 7633 & -109 \\
\hline 9 & 6766 & 7043 & 6956 & -428 \\
\hline 10 & 6291 & 8367 & 6415 & -2402 \\
\hline 11 & 9564 & 9540 & 9622 & -126 \\
\hline 12 & 8644 & 8722 & 8707 & -150 \\
\hline 13 & 7716 & 7843 & 7780 & -224 \\
\hline 14 & 6778 & 6933 & 6845 & -300 \\
\hline 15 & 5831 & 6006 & 5898 & -354 \\
\hline 16 & 4873 & 5073 & 4939 & -401 \\
\hline 17 & 3905 & 4141 & 3970 & -446 \\
\hline 18 & 2926 & 3222 & 2998 & -495 \\
\hline 19 & 1937 & 2340 & 2029 & -549 \\
\hline 20 & 935 & 1562 & 1132 & -609 \\
\hline 21 & 0.8 & 1322 & 606 & -800 \\
\hline
\end{tabular}

The following Fig.(16-to19) result of TITANUM alloy blade,it was observed that the highest value of the stresses at the base of the airfoil and gradually decrease as the hight reaches the top of the blade to reach the least value of the stresses where the stresses are located at the back of the base of the airfoil, and Table(6) show the average stresses on TITANUM alloy.

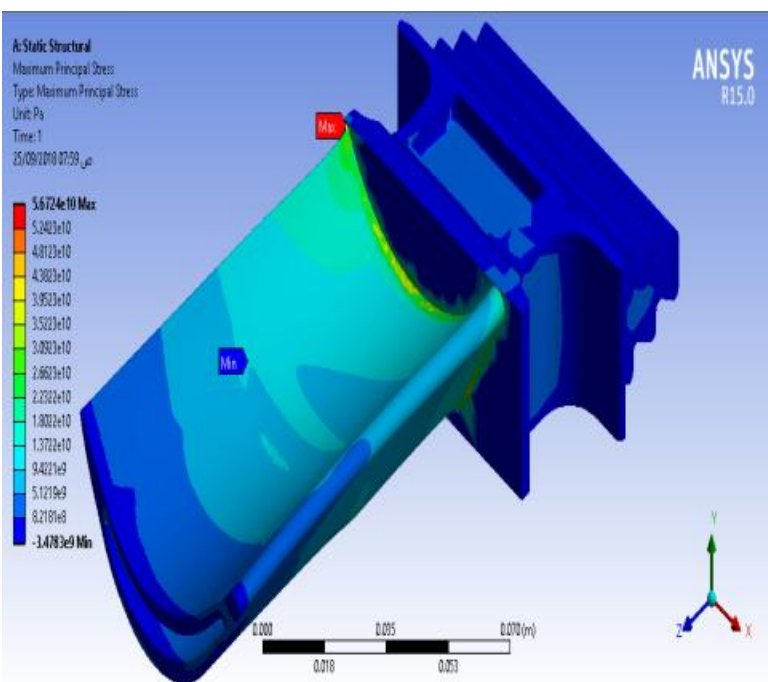

Fig. 16 Shows themaximum principle stress for TITANUM alloy blade.

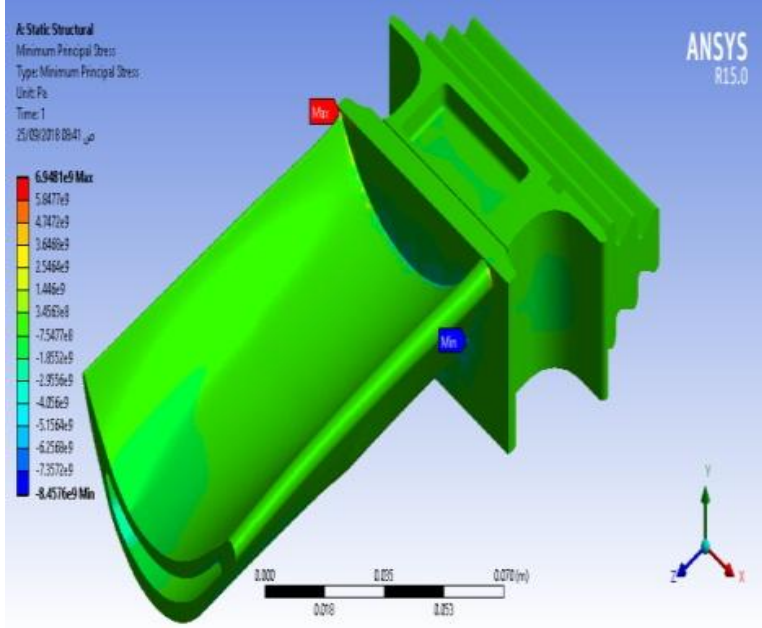

Fig. 17 Shows theminimum principle stress for TITANUM alloy blade.

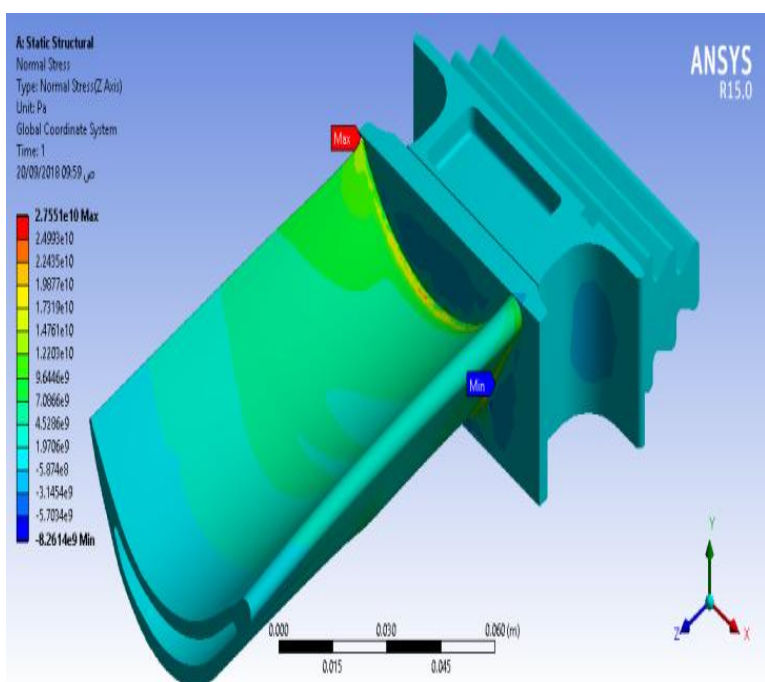

Fig. 18 Shows thenormal stress for TITANUM alloy blade.

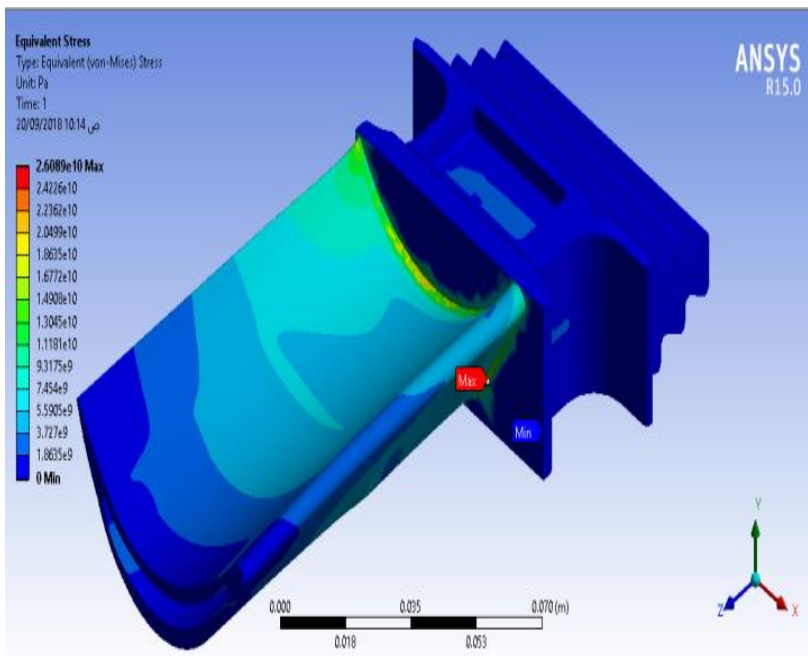

Fig. 19 Shows the Von misses stress for TITANIUM alloy blade. 
Table 6: Result of average stress analysis on blade of gas turbine made of TITANIUM alloy by ANSYS program in all sections along the blade.

\begin{tabular}{|c|c|c|c|c|}
\hline $\begin{array}{c}\text { Section } \\
\text { No. }\end{array}$ & $\begin{array}{c}\text { Normal } \\
\text { stress } \\
\text { (MPa) }\end{array}$ & $\begin{array}{l}\text { Von } \\
\text { misss } \\
\text { stress } \\
(\mathrm{MPa})\end{array}$ & $\begin{array}{c}\text { Maximum } \\
\text { principle } \\
\text { stress } \\
(\mathrm{MPa})\end{array}$ & $\begin{array}{c}\text { Minimum } \\
\text { principle } \\
\text { stress } \\
(\mathrm{MPa}) \\
\end{array}$ \\
\hline 1 & 6637 & 5540 & 6760 & 1362 \\
\hline 2 & 6031 & 5535 & 6504 & 552 \\
\hline 3 & 5963 & 5530 & 6004 & 130 \\
\hline 4 & 5601 & 5379 & 5625 & 22 \\
\hline 5 & 5223 & 5110 & 5250 & 7 \\
\hline 6 & 4832 & 4791 & 4867 & 6 \\
\hline 7 & 4430 & 4433 & 4473 & 0 \\
\hline 8 & 4014 & 4027 & 4064 & -58 \\
\hline 9 & 3603 & 3750 & 3704 & -228 \\
\hline 10 & 3350 & 4455 & 3416 & -1279 \\
\hline 11 & 5097 & 5080 & 5123 & -67 \\
\hline 12 & 4603 & 4644 & 4636 & -79 \\
\hline 13 & 4109 & 4176 & 4140 & -119 \\
\hline 14 & 3609 & 3691 & 3644 & -160 \\
\hline 15 & 3105 & 3198 & 3140 & -186 \\
\hline 16 & 2595 & 2701 & 2630 & -214 \\
\hline 17 & 2079 & 2205 & 2115 & -238 \\
\hline 18 & 1559 & 1715 & 1597 & -264 \\
\hline 19 & 1031 & 1245 & 1080 & -292 \\
\hline 20 & 498 & 831 & 602 & -324 \\
\hline 21 & 0.4 & 704 & 322 & -426 \\
\hline
\end{tabular}

The following Fig. $(21,22,23,24)$ comparison for all alloys used in current research. The concentration of the stresses is at the base of the airfoil for all the alloys used in this study.and the resulting stresses, such as normal stress,maximum\&minimum principle stress and von misses stresswhich were analyzed by the ANSYS software are lower in Titanium alloy than other alloys because the density of Titannium is less than the density of other alloys.

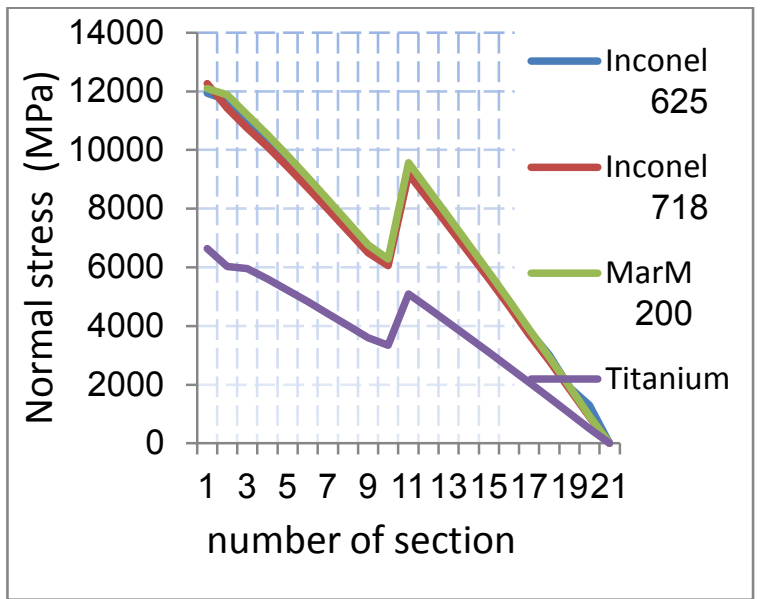

Fig. 21 Shows thecomparison of normal stresses for four different alloys used in this study.

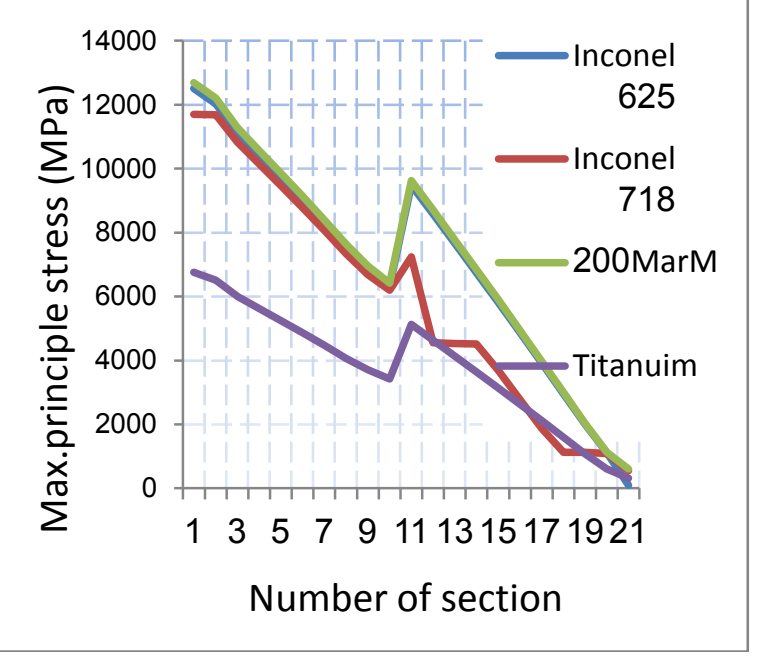

Fig. 22 Shows comparisonof Maximum principle stresses for four different alloys used in this study.

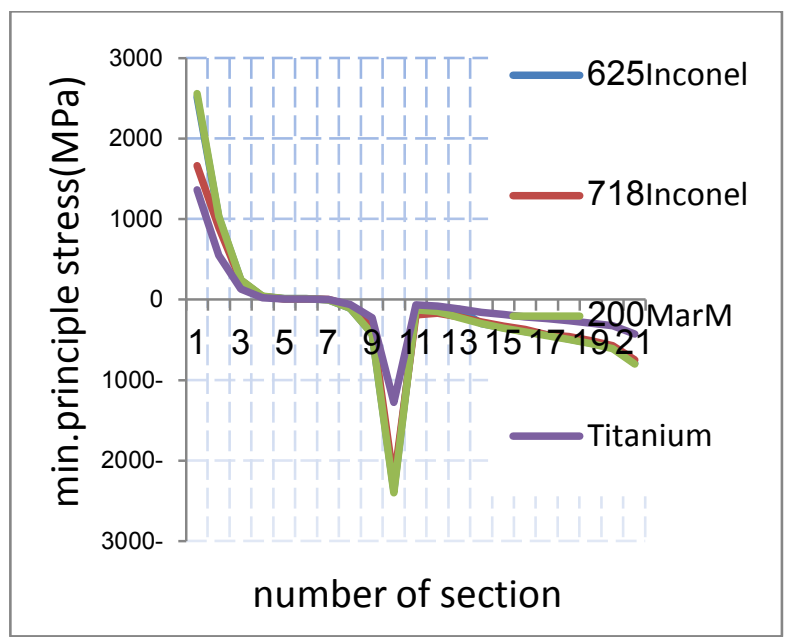

Fig. 23 Shows comparison of Minimum principle stresses for four different alloys used in this study.

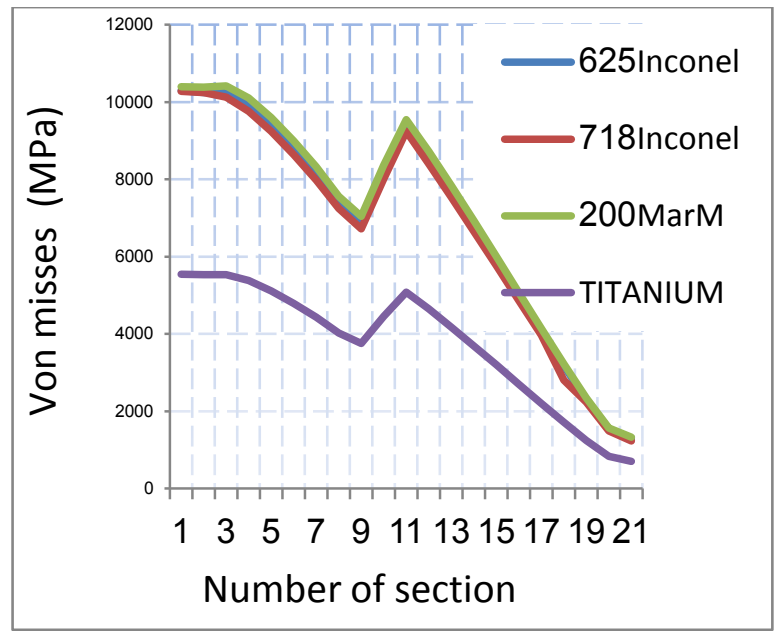

Fig. 24 Showscomparison of Von misses stresses for four different alloys used in this study. 


\section{CONCLUSION}

The results achieveddue to the centrifugal forces on the blade is debated below. 1-It was conclusion that the stresses produced by the centrifugal forces (normal stress, maximum and minimum principle stress, von misses stress) were concentrated at the base airfoil from the back.

2-It was observed that stresses along the blade be higher value when back to the root and less at the top of the blade as shown in Fig. $(21,22,23,24)$.

3-The centrifugal force depends on the mass where all less than the mass of the blade less centrifugal force and thus reduce the stresses resulting from this force, which was observed in the Titanium alloy of less density compared with the other alloys .

4-The tensile strength(normal stress) of the centrifugal force on the blade made of the Titanium alloy density is less than the tensile stress caused by the other alloys because the Titanium alloy density is lower than that of the other alloys thiscauses to reduce centrifugal force then causes to reduce stresses as shown in Fig.(21).

5-Maximum principle stress of the blade made of Titanium alloy has less than the maximum principle stress of the blade made of alloy $\mathrm{s}$ Inconel625,Inconel718,MarM-200) because the Titanium alloy density is lower than that of the other alloys so causes to reduce centrifugal force then causes to reduce stresses as shown in Fig. $(22) \&$ Fig. $(4,8,12,16)$.

6-That the negative value of the minimum principle stress of all alloys used indicate that the blade is subjected to compression stress in some blade parts of all alloys used as shown in Fig.(23) .

7-It was noted that the highest stress equivalent to the blade made of Titanium alloy is $26089 \mathrm{Mpa}$, and the equivalent stress of the blade made of Inconel625 is $48271 \mathrm{Mpa}$, and the highest equivalent stress of blade made of Inconel718 is $47631 \mathrm{Mpa}$, and the equivalent stress on the blade made of Mar M200 is $48995 \mathrm{MPa}$ this shows that the best on the safe matter of the high stresses is the titanium alloy this is due to the fact that Titanuim alloy density is less than the density of the alloys used as shown in Fig. $(6,11,15,20)$.

8-It is conculosion thatthe Titanium alloy is the best alloy used in terms leading to reduce stresses due to centrifugal force, because density of Titanium alloy used is less than of other used alloys,so,leading a reduction in centrifugal forcess which are directly propotional to mass, there by reducing the stresses of these forces to the Titanium alloy that is density less than of the alloys used in this study.

9-It was noted that the results of stresses for the INCONEL718,INCONEL625 and MarM-200 alloys are closer, they are nicle base alloys and they have the nearestdensity

\section{REFERENCES}

[1] Ajit Prasad, K.Ramachandra, M.Pradeepand K.Kumar"Effect Of Rubbing Forces Due To Centrifugal Loading On Rotor Blades"(2004).

[2] SK Bhatti S Chandra Prasad D Radha Krishna IN Niranjan Kumar BVARao"LIFE EVALUATION METHOD FOR GAS TURBINE BLADES MADE OF INCONEL718 ALLOY" Proceedings of the 2nd WSEAS Int. Conference on Applied and Theoretical Mechanics, Venice, Italy,208, November( 2022, 2006).

[3] Mats Eskner "Mechanical Behavior of Gas Turbine Coatings" Royal Institute of Technology,Stockholm (2004).

[4] R.A. CLÁUdIO, C.M. BRANCO, E.C. GOMES, J. BYRNE" LIFE PREDICTION OF A GAS TURBINE DISC USING THE FINITE ELEMENT METHOD" 8AS JORNADAS DE FRACTURA,(2002).

[5] AHMED ABDULHUSSEIN JABBAR1, A. K. RAI2, P. RAVINDER REEDY" DESIGN AND ANALYSIS OF GAS TURBINE ROTOR BLADE USINGFINITE ELEMENT METHOD"International Journal of Mechanical and Production,ISSN(P): 2249-6890; ISSN(E): 2249-8001, Vol. 4,73-94, Issue 1, Feb (2014).

[6] P.V.Krishnakanth1, G.Narasa Raju2, R D V. Prasad3, R. Saisrinu4 ," Structural \& Thermal Analysis of Gas Turbine Blade by Using F.E.M" International Journal of Scientific Research Engineering \& Technology (IJSRET), Volume 2 Issue2 pp 060-065, ISSN 2278 0882,May (2013).

[7] Help of ANSYS program V (15.0),(2016).

[8] Theju V,Uday PS,PLV Gopinath Reddy,C.J. Manjunath, -Design and Analysis of Gas Turbine Blade, International Journal of Innovative Research in Science, Engineering and Technology, ISSN: 2319-8753,June,(2014).

[9] V.NagaBushanaRao,N.Niranjan Kumar,N.Madhulata,A.Abhijeet,Mechanical Analysis Of 1st Stage Marine Gas Turbine Bladell,International Journal Of AdvancedScience and andTechnology,pp.5764, vol.68,(2014). 
18 Suha Hashim Ahmed: Theoretical Stress Analysis of Gas Turbine .....

\title{
التحليل النظري لاجهاد اتريش التوربين الغازي المصنوع من سبائك مختلفة
}

\author{
* سهى هاشم أحمد * * غيداء ابراهيم حسين *** * مجيد علي عبد الرزاق

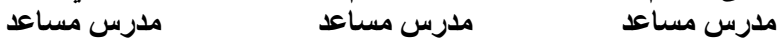

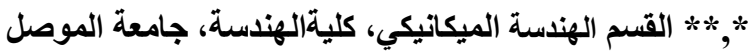

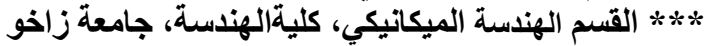

الخلاصة:

تعتبر الريش قلب التوربين وبدون الريش لا توجد طاقة وإن اي خلل فيها يؤدي الى انخفاض الكفاعة وبتصليحات مكلفة, استخدت العناصر

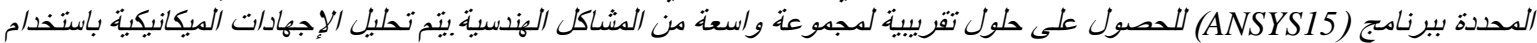

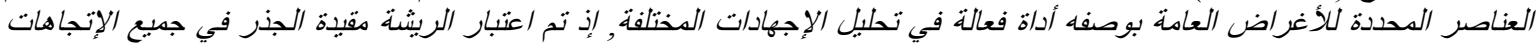

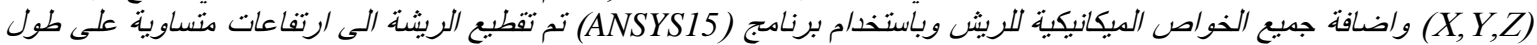

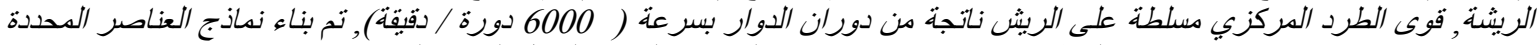

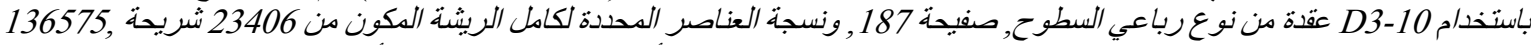

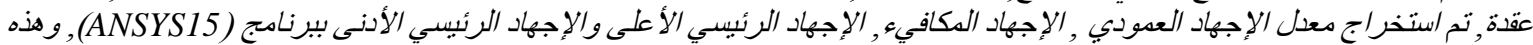

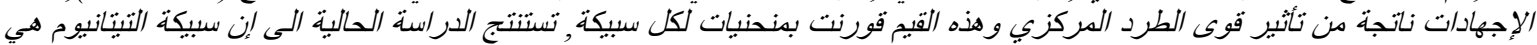

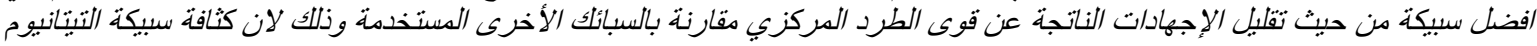

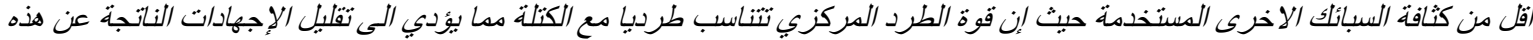

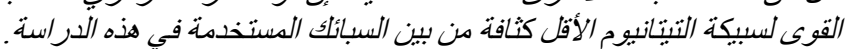
الكلمات الادالة. ريث التوربين الغازي,سبائك مختلفة تحللبل الإجهادات 